\title{
THE LYCOPODS (PHYLUM LYCOPODIOPHYTA); CLUBMOSSES, FIRMOSSES, SPIKEMOSSES AND QUILLWORTS, IN MANITOBA
}

\author{
RICHARD J. STANIFORTH 336 Glenwood Crescent, Winnipeg, MB, R2L 1J9. \\ Email: richard_staniforth@yahoo.ca
}

The lycopods fascinate many of us because they are the most ancient and primitive of all living vascular plants. Fossil relatives are traceable to the swamp forests of the late Carboniferous Period more than 320 million years ago, well before the dinosaurs reached their peak diversity. ${ }^{1}$ Although some ancient lycopods were large trees and grew to $55 \mathrm{~m}$ (165feet) in height, ${ }^{2}$ today's species are modest and many superficially resemble large moss plants. ${ }^{3}$ The name "lycopod" is derived from the appearance of leafy shoots which are supposed to resemble the feet of wolves! ${ }^{4}$ Most clubmosses, firmosses and spikemosses in Canada grow in grasslands, on forest floors, or in the forest-tundra, alongside the relatively modern seed-forming plants; the conifers and flowering plants (Fig. 1). ${ }^{3}$ Quillworts are an unusual group of lycopods in that they are aquatic or semi-aquatic, and grass-like in appearance (Fig. 1). ${ }^{3}$

We urgently need to catalogue and make range maps for all groups of organisms, such as lycopods, in our provinces, states and countries. ${ }^{5}$ The anticipated great changes in climate and landscapes will inevitably result in drastic adjustments in abundances and distributions. It is necessary to obtain as much current baseline data as possible for future reference. ${ }^{5}$ Such a study is timely for lycopods because there have been recent changes in their classification and nomenclature. ${ }^{6}$ We barely know what species we have!

\section{Materials and Methods}

During 2009, 2010 and 2011, I examined all 720 lycopod specimens that had been collected in Manitoba and housed in Manitoba herbaria; the Manitoba Museum (MMMN), Universities of Manitoba (WIN) and Winnipeg (UWPG), and in my own, non-registered collection ("RS"). The identity of each specimen was checked using the identification keys from the Flora of North America and Haines. ${ }^{6,7}$ Nomenclature of specimens was updated and annotations were applied when necessary. The collection numbers, locations, habitats, dates and other information were initially recorded in an Excel spreadsheet. Location information were converted to Universal Transverse Mercator (U.T.M.) grid, North American Datum 1983 (N.A.D. 83) values, but only if the herbarium sheet data had been sufficiently precise.

There are several popular ways to illustrate the ranges of species, including the use of dots or shading. ${ }^{3,7}$ In this study, a decision was made to show occurrences as dots in the $29150 \times 50 \mathrm{~km}$ squares that comprise the U.T.M. grid (N.A.D. 83) for the Province of Manitoba. This is in accordance with plant distribution maps that have been used successfully for plants and other biota in Europe and other parts of the world, ${ }^{8}$ and they are anticipated to become more widespread in Canada. ${ }^{5}$ It provides a comparative approach in range map presentation. In this study, a distribution map was made 
Table 1. Numbers of specimens of lycopods in Manitoba herbaria (MMMN, UWPG, WIN and the author's collection), numbers of UTM squares in which the specimens were collected out of 6068 squares (10X $10 \mathrm{~km})$ and out of 291 squares (50 x 50 $\mathrm{km})$, and rankings according to NatureServe Canada. ${ }^{9}$ NatureServe Conservation Status Ranks are: $G=$ Global, $S=S$ Subnational (i.e. Province of Manitoba), $1=$ Very rare, 2= Rare, 3=Uncommon, 4=Abundant with possible known threats, 5=Abundant and secure, $N R=$ Species not ranked.

\begin{tabular}{|c|c|c|c|c|c|}
\hline Clubmoss family & Lycopodiaceae & $\begin{array}{l}\text { Herbarium } \\
\text { specimens }\end{array}$ & $\begin{array}{c}10 \times 10 \\
\text { km UTM } \\
\text { squares } \\
\text { occupied }\end{array}$ & $\begin{array}{c}50 \times 50 \\
\text { km UTM } \\
\text { squares } \\
\text { occupied }\end{array}$ & $\begin{array}{c}\text { Conservation } \\
\text { Status Rank }\end{array}$ \\
\hline Prickly tree clubmoss & $\begin{array}{l}\text { Dendrolycopodium } \\
\text { dendroideum }\end{array}$ & 106 & 70 & 30 & G5 S5 \\
\hline Hickey's tree clubmoss & D. hickeyi & 20 & 19 & 15 & G5 S2 \\
\hline Northern ground-cedar & $\begin{array}{l}\text { Diphasiastrum } \\
\text { complanatum }\end{array}$ & 38 & 30 & 24 & G5 S5 \\
\hline Sitka clubmoss & D. sitchensis & 1 & 1 & 1 & G5 S1 \\
\hline Blue ground-cedar & D. tristachyum & 14 & 11 & 9 & G5 S2 \\
\hline Savin-leaved ground-cedar & D. x sabinifolium & 21 & 20 & 18 & G4 S4 \\
\hline Zeiller's ground-cedar & D. $\mathrm{x}$ zeilleri & 58 & 30 & 14 & GNR SNR \\
\hline Unidentified ground-cedars & Diphasiastrum spp. & 40 & & & \\
\hline Northern bog clubmoss & Lycopodiella inundata & 3 & 2 & 2 & G5 S1 \\
\hline Common clubmoss & Lycopodium clavatum & 41 & 20 & 8 & G5 S4 \\
\hline One-cone clubmoss & Lycopodium lagopus & 40 & 33 & 20 & G5 S4 \\
\hline Common interrupted clubmoss & Spinulum annotinum & 154 & 88 & 46 & G5 S5 \\
\hline Canadian interrupted clubmoss & Spinulum canadense & 42 & 36 & 31 & GNR SNR \\
\hline Firmoss family & Huperziaceae & & & & \\
\hline Mountain firmoss & Huperzia appressa & 7 & 6 & 5 & GNR SNR \\
\hline Shiny firmoss & H. lucidula & 0 & 0 & 0 & G5 SNR \\
\hline Northern firmoss & H. selago & 9 & 8 & 7 & G5 S2S3 \\
\hline Butters' firmoss & H. x buttersii & 3 & 2 & 2 & GNR SNR \\
\hline Spikemoss family & Selaginellaceae & & & & \\
\hline Prairie spikemoss & Selaginella densa & 16 & 10 & 9 & G5 S3 \\
\hline Rock spikemoss & S. rupestris & 78 & 51 & 30 & G5 S5 \\
\hline Northern spikemoss & S. selaginoides & 8 & 6 & 6 & G5 S2 \\
\hline Quillwort family & Isoetaceae & & & & \\
\hline Lake quillwort & Isoetes lacustris & 6 & 6 & 5 & G5 S2 \\
\hline Spiny-spored quillwort & Isoetes echinospora & 15 & 10 & 8 & G5 S4 \\
\hline
\end{tabular}


for each species; each dot on the map indicated that at least one specimen that had been collected from that particular 50 x $50 \mathrm{~km}$ square.

\section{Results and Discussion}

Seven hundred and twenty specimens of lycopods were examined. These consisted of four families (clubmosses, firmosses, spikemosses and quillworts; see Fig 1), eight genera, seventeen species and at least three wellestablished hybrids (Table 1). This table also shows the number of specimens of each species together with their global and provincial conservation status ranks. ${ }^{9}$ With few exceptions, lycopods are equally conspicuous, such that a difference in numbers of specimens likely reflected real differences in species abundances. Unfortunately, the same cannot be said of the northern bog clubmoss and northern spikemoss which are both inconspicuous and their apparent rarity may be due to under collection. ${ }^{3}$ Similarly, quillworts are easily overlooked, not because of rarity, but because their submerged habitat.

One of the exciting features of studies like this one is the chance that new taxa for the study area may turn up in addition to those that had been previously recorded. ${ }^{10,11,12}$ This happened twice; firstly with the recognition of Hickey's tree clubmoss as a Manitoba species (Fig. 2) and secondly that the commonest ground cedar in SE Manitoba was actually the hybrid taxon, Zeiller's ground-cedar (Fig. 5).

Many clubmosses occur in similar habitats to each other with the result that it was not unusual to find several species growing in close proximity. In SE Manitoba; Zeiller's ground-cedar, prickly tree clubmoss, interrupted clubmoss and the common clubmoss often occurred together in the mossy ground floras of mixed forests. With few exceptions, disturbance appeared to be a factor that was detrimental to the longevity of clubmoss colonies. Fires, clearance for agriculture and certain logging practices, such as scarification and trenching, usually resulted in the rapid disappearance of these species from an area. This probably accounted for their scarcity or complete absence from SW Manitoba, Birds Hill Provincial Park, ${ }^{13}$ Manitoba's Interlake region, the sandy esker region of NW Manitoba, and so on. In the absence of disturbance, colonies may occupy tens or even hundreds of square metres and reflect the time interval since the last disturbance.

Differences between the lycopod genera; clubmosses, tree clubmosses, the bog clubmoss, ground cedars, interrupted clubmosses, spikemosses, firmosses and quillworts are striking and usually do not cause confusion. On the other hand, differences between species within certain genera are more subtle and can be challenging. Hybridization between species adds a further level of complication to the identification of firmosses and ground-cedars. . $^{3,6} 7$ For these reasons, an identification key of Manitoba taxa is given; an annotated checklist, and figures are provided to describe provincial distributions and habitats. 


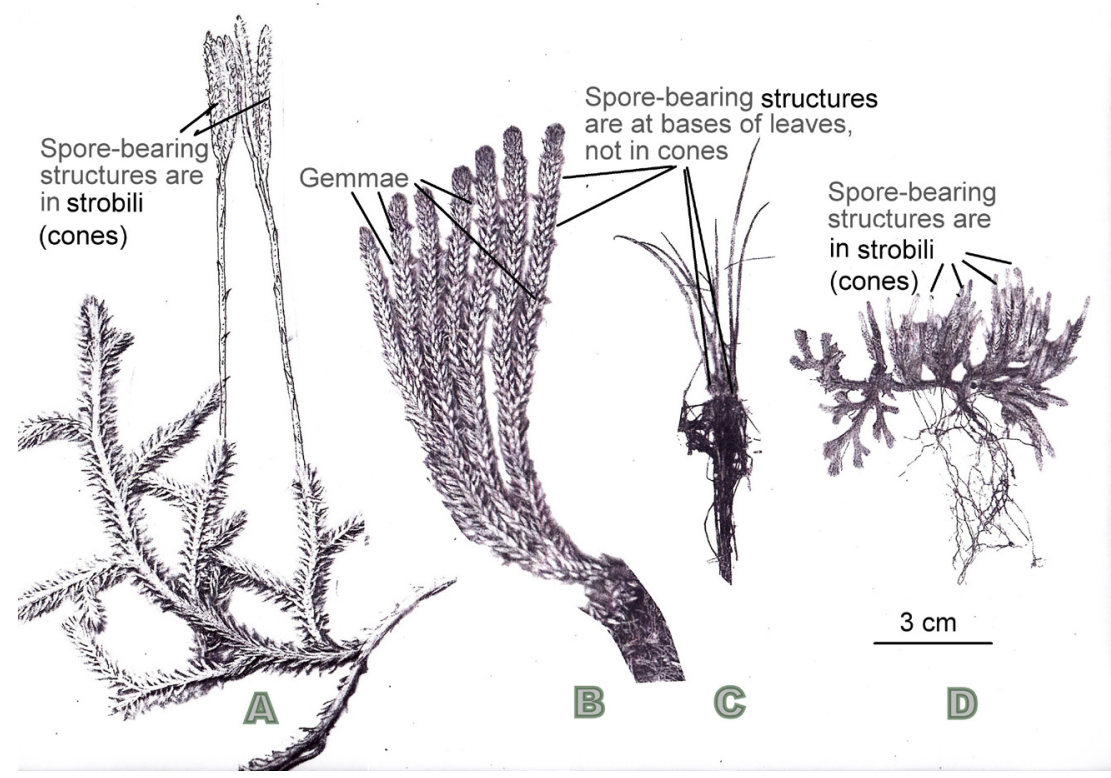

Figure 1. The four families of lycopods found in Manitoba: A. Clubmosses, B. Firmosses, C. Quillworts, D. Spikemosses. Note that the spore-bearing structures, or sporangia, are aggregated into cones or strobili in A. and D. but not in B. and C. Gemmae, or propagating buds, eventually fall from the parent plant and develop into new plants; these are found in B. only.

\section{Key to the families of lycopods found in Manitoba}

1a. Plants are terrestrial, creeping with above-ground or subterranean rhizomes (horizontal stems) and upright shoots. The stems are covered by numerous, small, evergreen leaves. 2.

1b. Plants of Manitoba species are submerged aquatic macrophytes. Each plant has a short, bulbous stem and a crown of long quill-like leaves.

..Quillworts (Isoëtaceae)

2a. Sporangia are in the axils of specialized leaves (sporophylls), which themselves are clustered at the tips of shoots into strobili (cones). Vegetative propagating buds (gemmae) are absent.

2b. Sporangia develop in the axils of ordinary leaves and are not arranged in distinct cones (strobili). Conspicuous gemmae are present on the shoots.

3a. Plants resemble giant moss plants, much taller than $4 \mathrm{~cm}$. Strobili cylindrical, not flat-sided. The spores are all tiny. Clubmoss family (Lycopodiaceae) 3 b. Plants resemble tiny moss plants, rarely over $4 \mathrm{~cm}$ tall. Strobili (cones) are 4-sided (or cylindrical in the rare Northern spikemoss). Sporangia with two-kinds of spores; large megaspores and tiny microspores 


\section{Key to genera and species of clubmosses found in Manitoba}

1a. Plants; small creeping annual with strobili (cones) clothed with green leaves and resemble "bushy tails" Lycopodiella inundata 1b. Plants; robust, perennial and evergreen with cylindrical strobili. These are clothed with sporophylls (scales) not resembling the normal leaves

2a. Youngest shoots, incl. leaves; 5 to $12 \mathrm{~mm}$ wide; round in cross-section; leaves many ranked on stems

2b. Youngest shoots, incl. leaves; 2 to $6 \mathrm{~mm}$ wide, flat in cross-section (except in $D$. sitchense); leaves 4-ranked (or 5-ranked in D. sitchense) on stem

Diphasiastrum (go to 8)

3a. Stems tree-like, with single vertical axis and numerous horizontal branches

Dendrolycopodium (go to 4 )

3b. Stems not tree-like, but creeping along surface of ground and giving rise to numerous upright branches

4a. Leaves of main stem below the branches stand at right angles to stem. The main stems feel prickly to touch. Dendrolycopodium dendroideum 4b. Leaves of main stem below the branches are incurved. The main stems feel smooth to touch. Dendrolycopodium hickeyi

5a. Strobili sessile (without stalks); leaves bristly and prickly to touch; annual growth increments are made conspicuous by constrictions amongst the stem leaves Spinulum (go to 6) 5b. Strobili on long stalks; leaves soft and hair-tipped, not prickly; the annual growth increments are not highly conspicuous Lycopodium (go to 7 )

6a. Leaves 3.0 to $5.9 \mathrm{~mm}$ long, usually not toothed. Leaves located above each annual constriction are broadest near their bases. Leaf clearly margins are not toothed or are only obscurely toothed. Strobili 0.8 to $1.7 \mathrm{~cm}$ Spinulum canadense 6b. Leaves 5.2 to $9.8 \mathrm{~cm}$ long, usually clearly toothed. Leaves located above each annual constriction are widest near or above their middles. Leaf margins are clearly toothed. Strobili 1.7 to $4.3 \mathrm{~cm}$ long.

Spinulum annotinum

7a. Strobili one (occasionally 2) per stalk; above-ground stems with few (usually 3 or less) upright branches Lycopodium lagopus

7b. Strobili 2-4 (rarely single) per stalk; above-ground stems with many spreading branches Lycopodium clavatum

8a. Branches flat; tiny leaves attached to the branches for most of their lengths. The leaves are in four rows on the branches, i.e. above, below, and on the two sides of the branches

8b. Branches slightly flattened to round in section; leaves attached to the stems only at their bases and in four or five rows

9a. Horizontal stems on or near soil surface, but often under moss or leaf litter; peduncles with 1 (occasionally 2 ) strobilus ................ Diphasiastrum complanatum 9b. Horizontal stems subterranean; peduncles with 2 or 4 strobili 
10a. Branchlets flat and wide ( $>2 \mathrm{~mm}$ ) ventral leaves about half the lengths of dorsal leaves; foliage glossy, dark green........................... Diphasiastrum x zeilleri) (The Zeiller's ground-cedar is common in SE Manitoba and is often confused with one of its parents, northern ground-cedar, from which it differs by its subterranean stems and because it has 2-4 strobili per peduncle. The other parent species is the blue ground-cedar.)

10b. Branchlets flat but narrow ( $<2 \mathrm{~mm})$, almost cord-like; ventral leaves almost as long as dorsal leaves; foliage with bluish appearance

Diphasiastrum tristachyum

11a. Strobili sessile to short $(<1 \mathrm{~cm})$ stalked; when present, peduncles (stalks) do not possess fertile sporophylls along their lengths Diphasiastrum sitchense 11b. Strobili stalked, the upper parts of the peduncles have scattered sporophylls containing sporangia. Diphasiastrum $x$ sabinifolium (The savin-leaved ground-cedar is the hybrid between the blue and Sitka groundcedars and is quite variable. Plants reflect various proportions of characters of each parent species.)

\section{Key to species of firmosses found or expected to be found in Manitoba}

1a. Leaves toothed; dark green, shiny; parallel sided to widest above middle. Stems with conspicuous annual constrictions. Usually found in shady woods....

1b. Leaves not toothed; parallel sided to widest at base; yellow, yellowish-green or green, shiny or dull. Usually found in open sites e.g. rock outcrops, bogs or wet tundra.

2a. Leaves broadest above their middles with conspicuous teeth on the leaf margins; spores in sporangia spherical and healthy..... Huperzia lucidula

$\mathbf{2 b}$. Leaves parallel sided with few or tiny teeth on the leaf margins; spores in sporangia misshapen and aborted

Huperzia x buttersii

3a. Gemmae (vegetative buds) are arranged in single whorls (rings), each located at the apex of an annual growth segment........................... Huperzia selago 3b. Gemmae are arranged in several whorls at the apex of each growth segment of the stem, or scattered throughout the stem

Huperzia appressa

\section{Key to spikemosses found in Manitoba}

1a. Leaves pointed but not bristle-tipped, strobilus cylindrical, sporophylls spreading. Rare plant of alkaline fens and damp areas........Selaginella selaginoides 1b. Leaves bristle-tipped. Strobilus square in cross-section, sporophylls appressed. Common plants of dry rocks and sandy soils

2a. Plants form dense, tufted clumps. Shoot tips appear to be upturned and with a distinct, terminal brush of leaves when dry. Fresh shoots appear silvery and frostytipped because of the concentrations of bristle-tipped leaves...... Selaginella densa 2b.Plants form loose clumps or spreading. Shoot tips appear to be straight and without dense terminal brushes of leaves when dry. Fresh shoots appear green.... 


\section{Key to species of quillworts found in Manitoba}

1. Leaves curved outwards, yellow-green and tapering gradually towards their tips. Megaspores covered by short spines. Usually found in lakes and slow rivers that are $<1.5 \mathrm{~m}$ deep. Isoëtes echinospora

2. Leaves more or less, straight and upright, dark-green, abruptly tapered at their tips. Megaspores covered with ridges but possessing a girdle of short spines. Usually found in lakes that are $1.5 \mathrm{~m}$ or more deep. Isoëtes lacustris

\section{Annotated checklist of Lycopods found in Manitoba}

1. Prickly tree clubmoss, Dendrolycopodium dendroideum (Michx.) A. Haines (Fig. 2)

Prickly tree-clubmoss is the common tree clubmoss in Manitoba. It inhabits moist mixed and coniferous forests, throughout the province except the agricultural southwest. It often co-occurs with other clubmosses, such Common and Interrupted clubmosses. It is common in boreal regions of Saskatchewan including Cypress Hills. ${ }^{4}$ Tree club-mosses, or Ground-pines, have vertical stems that are branched in the fashion of small trees. This species has leaves on the main stem that are held at right angles to it and give a prickly sensation to touch. Older texts refer to this species as Lycopodium obscurum L.

2. Hickey's tree clubmoss, Dendrolycopodium hickeyi (W.H. Wagner, Beitel \& Moran) A. Haines (Fig.2)

This is the first report of the Hickey's tree-clubmoss for Manitoba, where it's distribution and habitats are somewhat similar to those of the commoner Prickly tree club-moss. There is a single record of this species from Lake Athabasca in northwest Saskatchewan. ${ }^{4}$ In this species, the main stem feels smooth because its leaves are appressed to it. $6,14,15,16$ The two species of tree club-mosses have been found growing within 5 metres of each other in the SE Manitoba and yet had maintained their differences. It was formerly called Lycopodium obscurum variety isophyllum Hickey.

\section{Northern ground-cedar, Diphasiastrum complanatum (L.) Holub (Fig. 3)}

This species is common and widespread in Manitoba. It is found in the understory of several forest types from moist mixed to open dry pine/spruce woodland. It occurs throughout the boreal forest region of Saskatchewan and in the Cypress Hills. ${ }^{4}$ The common hybrid, Zeiller's ground cedar, has often been mistakenly identified as this species, especially in SE Manitoba. The northern ground cedar differs from the hybrid by having horizontal stems at or near the ground surface and peduncles with single strobili. This species was formerly called Lycopodium complanatum.

\section{Sitka clubmoss, Diphasiastrum sitchense (Rupr.) Holub (Fig. 3)}

Manitoba's single specimen of Sitka ground cedar was collected by E. Punter in NE Manitoba in July, 1991 (WIN 52607). ${ }^{10}$ This plant had been growing on mineral soil amongst short black spruce trees in an area, recovering from fire damage. The Sitka - Savin-leaved ground cedar complex is represented by scattered colonies across the northern half of Saskatchewan. ${ }^{4}$ The species was formerly known as Lycopodium sitchense. 
5. Blue ground-cedar, Diphasiastrum tristachyum (Pursh) Holub (Fig.4)

The Blue ground-cedar is rare but occurs in a band of colonies from SE to midWest Manitoba. It inhabits dry rock outcrops and sand hills in pine forests within the boreal forest region. It has not been reported from Saskatchewan. ${ }^{4}$ Compared to the Northern ground cedar, plants of this species differ by the bluish bloom on their foliage, subterranean rhizomes, fan-shaped arrangement of the narrow branches, prominent lower leaves and multiple strobili per peduncle. This species was formerly called Lycopodium tristachyum.

6. Savin-leaved ground-cedar, Diphasiastrum x sabinifolium (Willd.) Holub (D. sitchense $x$ D. tristachyum) (Fig. 4)

This is the commonest ground-cedar in northern Manitoba where it is found in open spruce or pine forests, eskers or on rocky outcrops. The Sitka-Savin-leaved groundcedar complex occurs as scattered colonies in northern Saskatchewan. ${ }^{4}$ Despite its hybrid origin, it may occur where one or both parent species are absent. Adjacent colonies may have different appearances; each with a set of attributes typical of one parent more than the other. Colonies form self-sustaining fertile populations. The presence of fertile, sporangia-bearing sporophylls below the strobili is a unique characteristic of this taxon. This hybrid was formerly known as Lycopodium $\mathrm{x}$ sabinifolium.

7. Zeiller's ground-cedar, Diphasiastrum x zeilleri (Rouy) Holub (D. complanatum $x$ D. tristachyum) (Fig. 5)

This is the commonest ground-cedar in SE Manitoba, where it is found on moist well-drained soils in mixed and coniferous forests. It is scarce elsewhere. This is the first report for Manitoba, because it has usually been misidentified as Northern groundcedar. Zeiller's ground-cedar has been reported from pine forests in N Minnesota, 3,7 but not from Saskatchewan. ${ }^{17}$ It is a hybrid of the northern and blue ground-cedars; forming self-sustaining fertile populations often far from either parent species. It is characterized by the presence of subterranean shoots and multiple cones typical of the blue ground cedar, but bearing tiny ventral leaves and wide shoots of its other parent, the northern ground-cedar.

Unidentified (vegetative) ground-cedars, Diphasiastrum spp.

Many specimens of ground-cedars were not fertile when collected and accurate identifications could not be made. Many appear to belong to the northern-blue-Zeiller's ground-cedar complex.

8. Northern bog clubmoss, Lycopodiella inundata (L.) Holub (Fig. 5)

Northern bog club-moss was collected by E. Punter from Nopiming Provincial Park, E. Manitoba in July, 1993 (WIN 55084, WIN 55312). ${ }^{10}$ In 2010, I found the site flooded and bog club-mosses were absent. In 2010, E. Punter discovered an unaccessioned 1996 collection from Singleton Lake, N Manitoba (WIN). It occurs at scattered locations in N Saskatchewan, and is listed as "vulnerable". ${ }^{17}$ The tiny plants of this annual species are easily overlooked. It should be searched for in wet, sandy, open sites within the boreal forest in mid to late summer. This species was once known as Lycopodium inundatum L. 


\section{Common clubmoss, Lycopodium clavatum L. (Fig. 6)}

The Common, Running or Stag's-horn clubmoss is locally common in undisturbed, mixed and coniferous forests in SE Manitoba. It is found in similar habitats to the closely related, but more widespread One-cone clubmoss. Both have leaves which terminate in a fine hair and both form extensive colonies by means of their spreading horizontal stems. The most obvious difference between the two species is that the Common clubmoss has cones that are arranged in 2-4 per peduncle, whereas shoots of its sibling species usually have single cones. The Common clubmoss is of uncertain status in Saskatchewan owing to its confusion with the One-cone clubmoss. ${ }^{4}$

\section{One-cone clubmoss, Lycopodium lagopus (C. Hartman) G. Zinserling ex Kuzeneva-Prochorova (Fig. 6)}

This boreal forest species is found from SE to NW Manitoba. It is more widespread and northern than the Common clubmoss and is more often found near rock outcrops. The species is common throughout the boreal forest region of Saskatchewan. ${ }^{4}$ It was once considered to be a variety of the Common clubmoss, i.e. L. clavatum L. var. monostachyon Hook. \& Grev.,11,12 however, it maintains its differences even when growing in the same vicinity, ${ }^{7}$ as they often do in SE Manitoba. Apart from its single strobili, this species differs by having fewer branches on its upright shoots than does the Common clubmoss.

\section{Common interrupted clubmoss, Spinulum annotinum (L.) A. Haines (Fig. 7)}

This species is the most abundant and widespread clubmoss in Manitoba. In common with several other clubmosses; it is found in moist, mixed and coniferous woodlands with organic soils. It is also common throughout the boreal forest region of Saskatchewan. ${ }^{4}$ Its upright stems have a distinctive stiff, bristly appearance. The sharp-pointed, shiny leaves are interrupted at intervals along the stems indicating different growth seasons and "interrupt" the outline of the shoots. Leaf shape and degree of marginal dentition is quite variable. Upright stems are branched at the base and produce single, sessile cones at their apices. This species was formerly known as Lycopodium annotinum L. $^{6}$

12. Northern interrupted clubmoss, Spinulum canadense (Ness.) A. Haines (Fig. 7)

This newly described species is the northern counterpart of the previous one. ${ }^{6}$ In Manitoba, the plants inhabit forest-tundra and tundra habits, or barrens within the boreal forest. Vertical shoots may appear to be tufted because they emerge at intervals from the horizontal shoots that are buried under moss or lichen mats. The leaves are shorter, thicker, more triangular, and more appressed than those of the former species. This species was once known as Lycopodium annotinum L. var. pungens (La Pylae) Desv. $3,11,12$

\section{Annotated checklist of firmosses (Family Huperziaceae)}

\section{Mountain firmoss, Huperzia appressa (Desv.) A. \& D. Löve (Fig. 8)}

This species is rare in both Manitoba and Saskatchewan. It has been found on moist sedge- heath tundra and in open black spruce bogs along the coastal Hudson Bay Lowlands. Mountain firmoss is sometimes difficult to separate from the next species from which it differs mostly by habitat and the location of gemmae. ${ }^{6}$ The latter are found throughout the lengths of the shoots rather than solely at the ends of annual growth 
increments. The entire plant turns yellow upon reaching maturity, before senescence occurs. This species was once considered part of the variation within the former species, Lycopodium selago L.

\section{Shining firmoss Huperzia lucidula (Michx.) Trev.}

There are currently no specimens of Shining firmoss in Manitoba herbaria; however, a specimen is reported to have been collected by J. Ritchie from near the East gate of Riding Mountain National Park. ${ }^{18}$ The whereabouts of this specimen is unknown, but a photograph is filed at the Dept. of Agriculture in Ottawa. It shows a non-fertile plant; unfortunately photographic definition is inadequate to allow necessary evaluation of leaf features and thus separate it from the otherwise similar interrupted clubmoss. The Shining fir-moss should be excluded from the provincial list until there is concrete evidence of its occurrence in the province. The species is found in adjacent parts of Ontario and Minnesota. ${ }^{7,19}$ Hybrids with Northern firmoss have been collected in Manitoba, near the Ontario border. It is absent from Saskatchewan. ${ }^{17}$

\section{Northern firmoss, Huperzia selago (L.) Bernh. ex Schrank \& Mart. (Fig. 8)}

There have been few colonies of this species discovered in Manitoba. They were located in the boreal forest at well-separated locations in the eastern and northern parts of the province. Most specimens had been collected from damp, shady granite outcrops or boulder slopes. Apart from habitat dissimilarities, this species varies from the mountain firmoss in the locations of its gemmae on its stems; see above. Specimens from northern Manitoba maybe hybrids with Mountain firmoss, i.e. $H$. $x$ josephbeitelii A. Haines, but there is an urgent need for more taxonomic study on all Manitoba firmosses. ${ }^{3}$ The northern firmoss is "vulnerable" in both Manitoba and Saskatchewan. ${ }^{17}$

4. Butters' firmoss, Huperzia x buttersii (Abbe) Kartesz \& Gandi (H. lucidula x H. selago) (Fig. 9)

Only three specimens of Butters' firmoss have been collected in Manitoba. Although this is a hybrid taxon, it apparently does not need the close proximity of either parent species. The three specimens had been collected from mixed and conifer forests in the SE corner of the province from amongst boulders, or on rock outcrops, in the vicinity of bogs. It has tiny teeth on the leaf margins; flat, parallel-sided leaves, and large gemmae which are arranged at the apices of annual stem growth increments, but it lacks the conspicuous teeth and obovate shapes of the leaves of the shining firmoss. This taxon has not beep reported from Saskatchewan, ${ }^{4}$ but has been found in adjacent parts of Minnesota.

\section{Annotated checklist of Spikemosses (Family Selaginellaceae)}

\section{Prairie spikemoss, Selaginella densa Rydberg (Fig. 9)}

The Prairie spikemoss is restricted to the prairies of southwest Manitoba; however, recently colonies have been found in the Interlake region on calcareous bedrock, and also east of Lake Winnipeg on granitic outcrops. It is usually associated with sparsely vegetated, sandy prairies amongst xerophytic lichens and mosses. Rock and Prairie spikemosses are easily confused. The length of the bristle at the leaf apex is usually given as the diagnostic character, but as Scoggan has pointed out, this feature is unreliable Scoggan. A far better guide is to examine the branch tips which are densely tufted in the Prairie spikemoss but not so in the other species. It is very common in southern Saskatchewan. ${ }^{4}$ 
2. Rock spikemoss, Selaginella rupestris (L.) Spring (Fig. 10)

This is a common species in eastern and mid-latitudes of Manitoba. It occurs on granitic outcrops with hair-mosses (Polytrichum spp.) and lichens, but it is also found in sandy, grassy places, and openings in pine forests. Its abundance on road allowances that pass through pine forests may indicate a tolerance of moderate disturbance and the ability to quickly exploit new sites. It is common on rock outcrops in the boreal forest of northern Saskatchewan. ${ }^{4}$ The small size of this and the preceding species make them easy to overlook amongst superficially similar mosses with which they are often associated. The spike-like strobili of spikemosses should separate them from mosses with ease.

\section{Northern spikemoss, Selaginella selaginoides (L.) P. Beauv. (Fig. 10)}

Plants of Northern spikemoss are small, inconspicuous and very difficult to spot amongst associated mosses. There have been few collections, which may suggest that it has been overlooked. As in Saskatchewan, this species occurs in two separate regions where it inhabits different ecosystems. ${ }^{4}$ In the Hudson Bay Lowlands of northern Manitoba it is found on wet, mossy, stream banks and lake shores, but in southern Manitoba it is more likely to be found in mossy calcareous fens and fen-bogs. It is provincially rare in Saskatchewan.

\section{Annotated checklist of Quillworts (Family Isoëtaceae)}

\section{Spiny-spored quillwort, Isoëtes echinospora Dur. (Fig. 11)}

The Spiny-spored quillwort is quite similar in appearance to the next species. It has been collected from shallow ponds, lakes or slow-running rivers in boreal ecosystems in $\mathrm{E}$ and $\mathrm{N}$ Manitoba. It often occurs in water less than 1 metre deep and sometimes can be seen from the shoreline but more likely seen after storms when uprooted plants are washed ashore. There are few collections from Manitoba, thus making its provincial distribution under-represented. This species tends to have yellower leaves which taper from their bases to the points, and the salt grain sized megaspores have spiny coverings. It is classified as uncommon in Saskatchewan. ${ }^{4}$

\section{Lake quillwort, Isoëtes lacustris L. (Fig. 11)}

There are few collections of Lake quillwort from Manitoba. This species occurs in low-nutrient lakes with sand or mud bottoms and submersed to depths up to $3 \mathrm{~m}$. Its presence is usually only discovered when uprooted plants are washed ashore after storms. Fragmented leaves are grass-like and resemble those of many other aquatic plants. Quillwort leaves have distinctive spoon-shaped leaf bases which may contain the reproductive spores. ${ }^{3,14}$ In this species, the leaves tend to be dark green, upright and only taper at the tip. Its megaspores do not have spiny processes on their surfaces, characteristic of the next species. It is rare in Saskatchewan where it has been found at three locations, all north of $58^{\circ}$ latitude. ${ }^{4}$

Figs. 2-11. Photographs and distribution maps of lycopods in Manitoba.

Photographs were taken by the author, and the original maps were made by Colin Murray. 

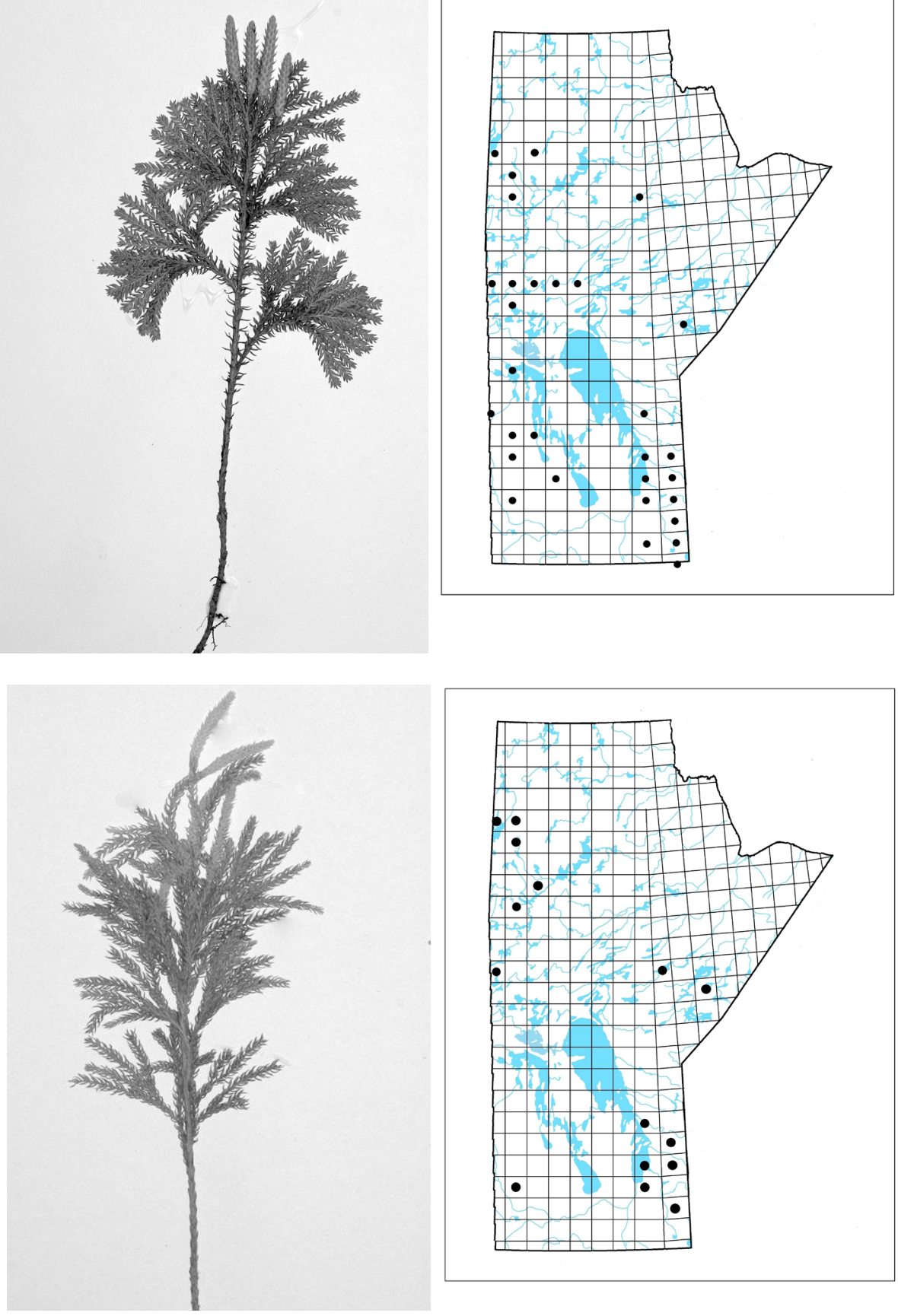

Figure 2. Upper photograph and map: Prickly tree clubmoss, Dendrolycopodium dendroideum. Lower photograph and map: Hickey's tree clubmoss,

Dendrolycopodium hickeyi. 

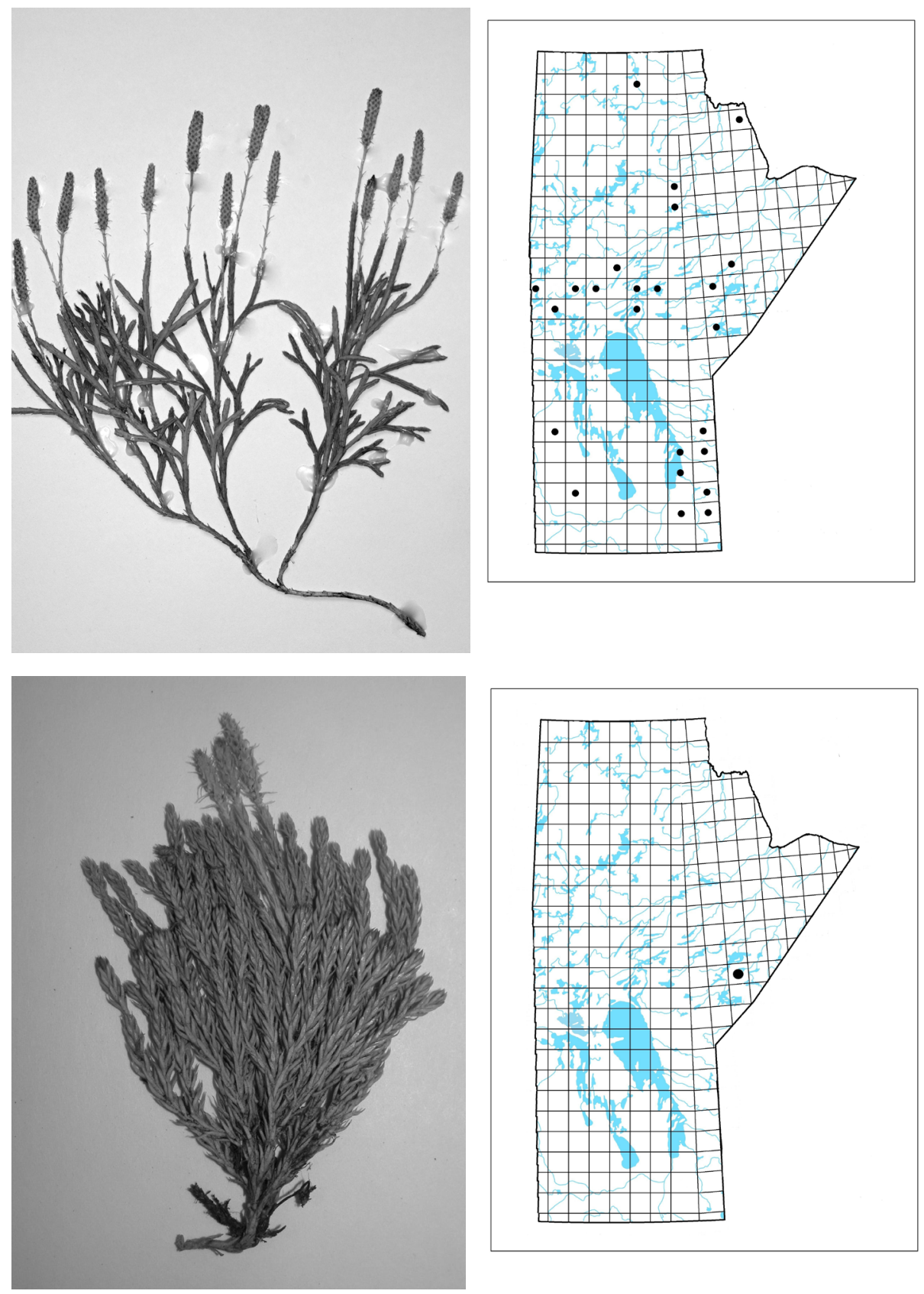

Figure 3. Upper photograph and map: Northern ground-cedar, Diphasiastrum complanatum. Lower photograph and map: Sitka clubmoss, Diphasiastrum sitchense. 


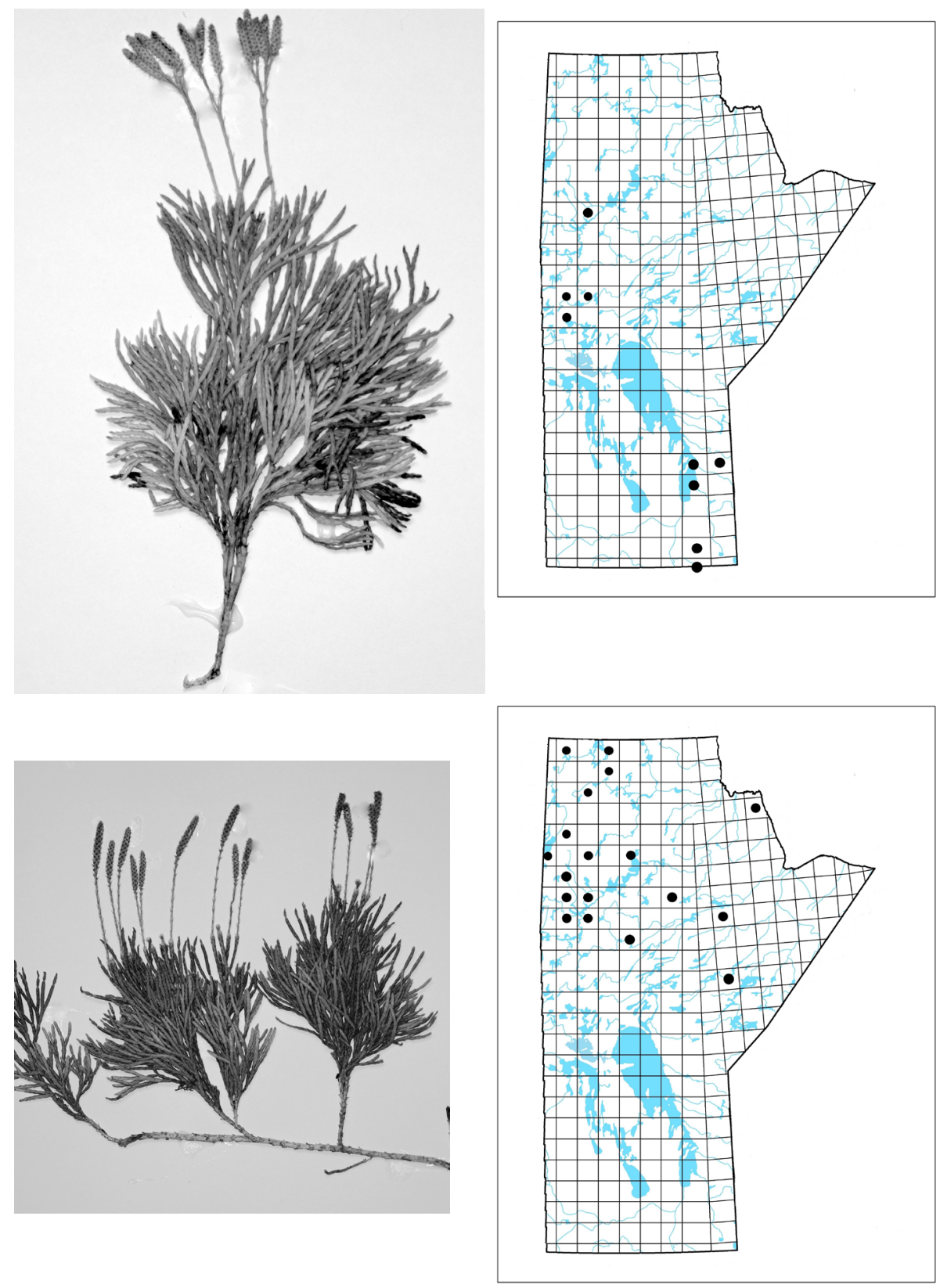

Figure 4. Upper photograph and map: Blue ground-cedar, Diphasiastrum tristachyum. Lower photograph and map: Savin-leaved ground-cedar, Diphasiastrum x sabinifolium. 

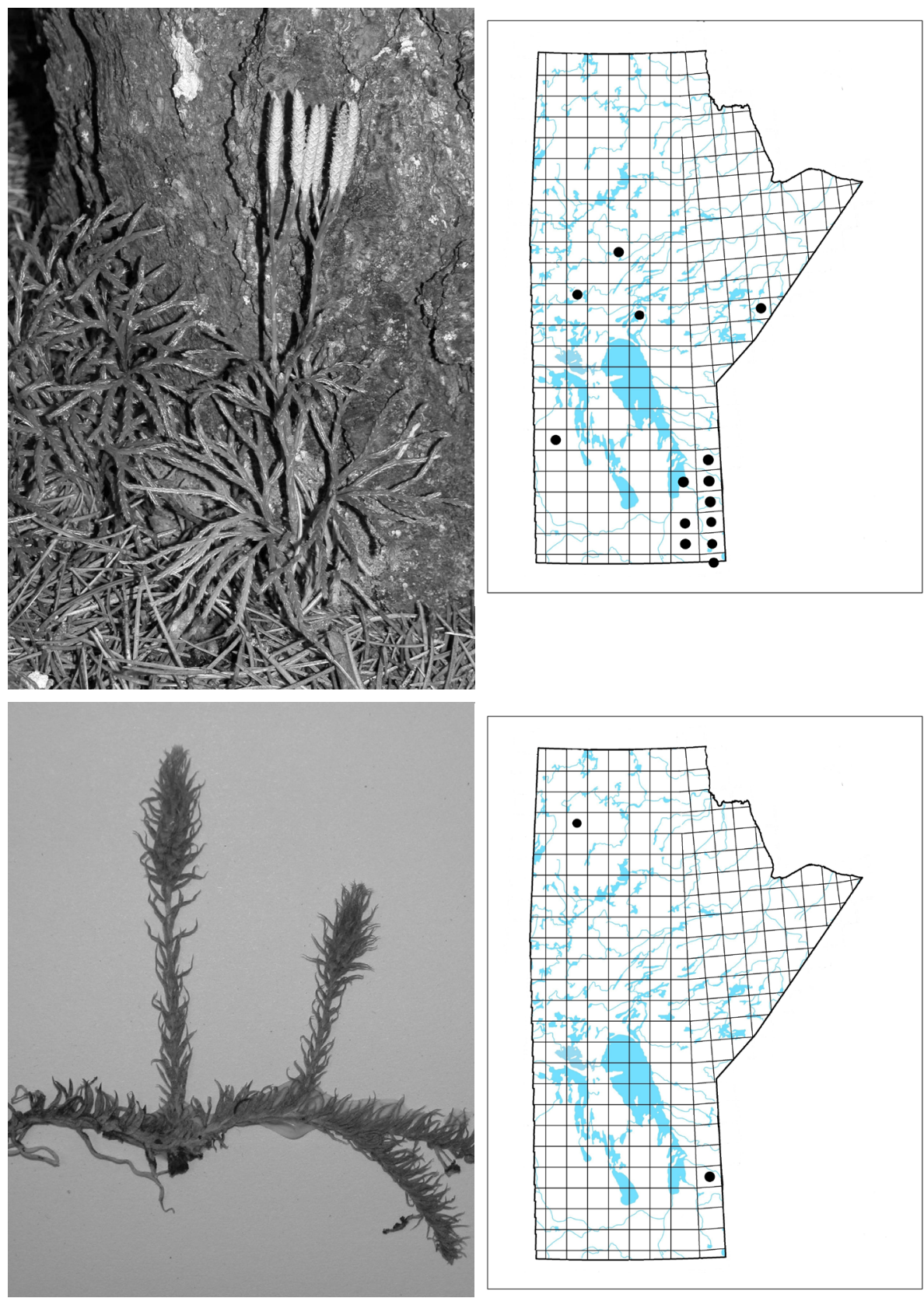

Figure 5. Upper photograph and map: Zeiller's ground-cedar, Diphasiastrum x zeilleri. Lower photograph and map: Northern bog clubmoss, Lycopodiella inundata. 


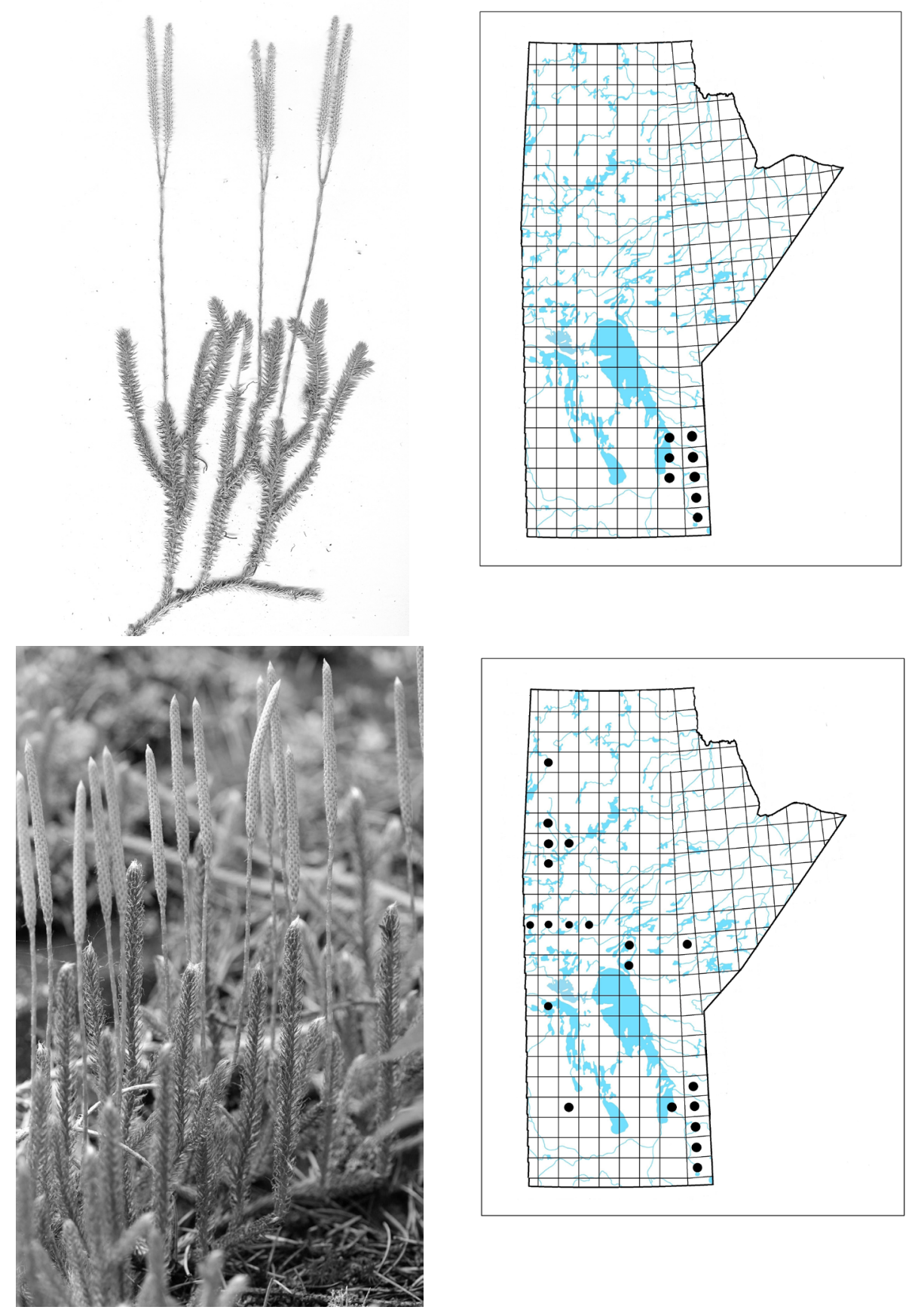

Figure 6. Upper photograph and map: Common clubmoss, Lycopodium clavatum. Lower photograph and map: One-cone clubmoss, Lycopodium lagopus. 

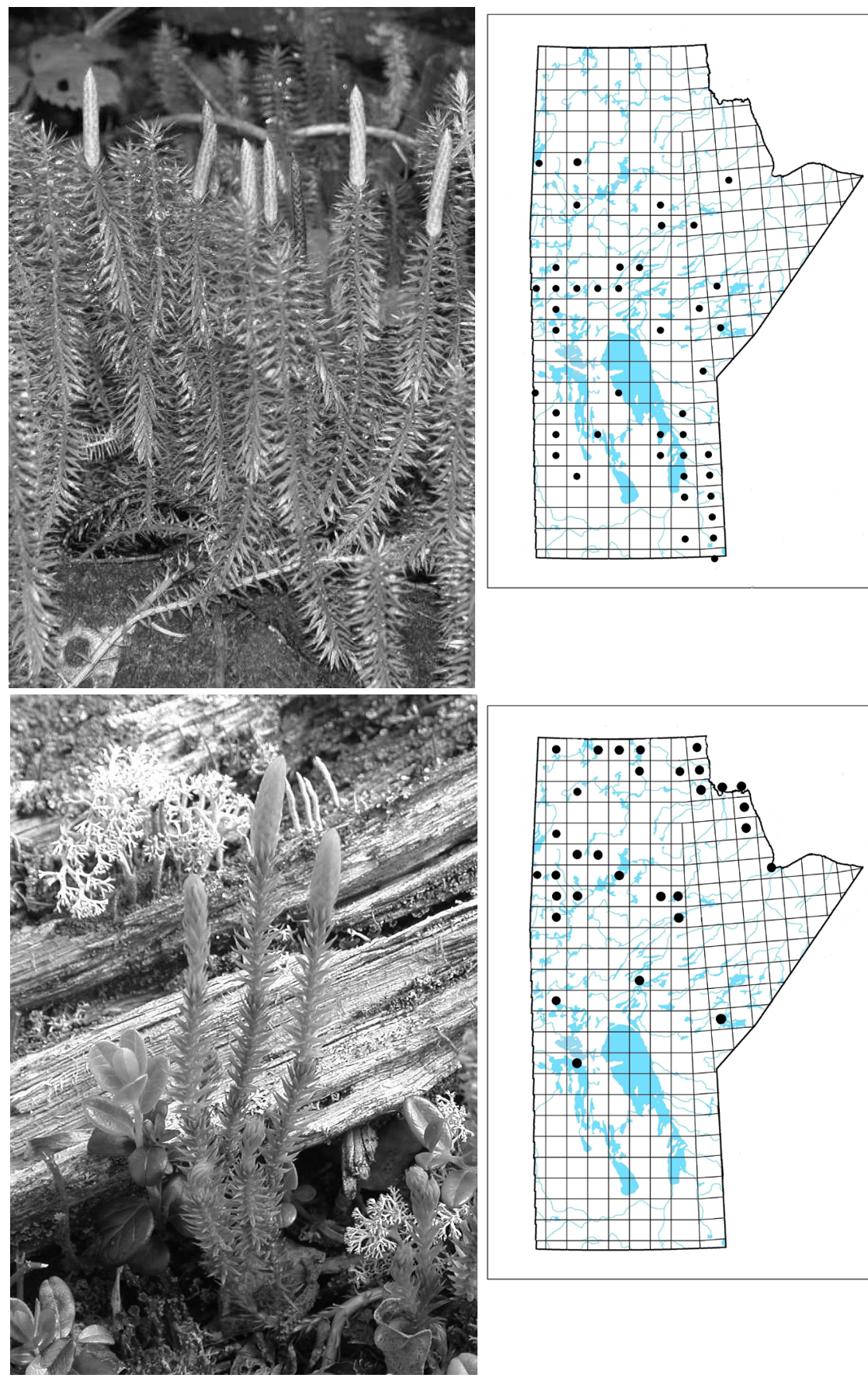

Figure 7. Upper photograph and map: Common interrupted clubmoss, Spinulum annotinum. Lower photograph and map: Northern interrupted clubmoss, Spinulum canadense. 

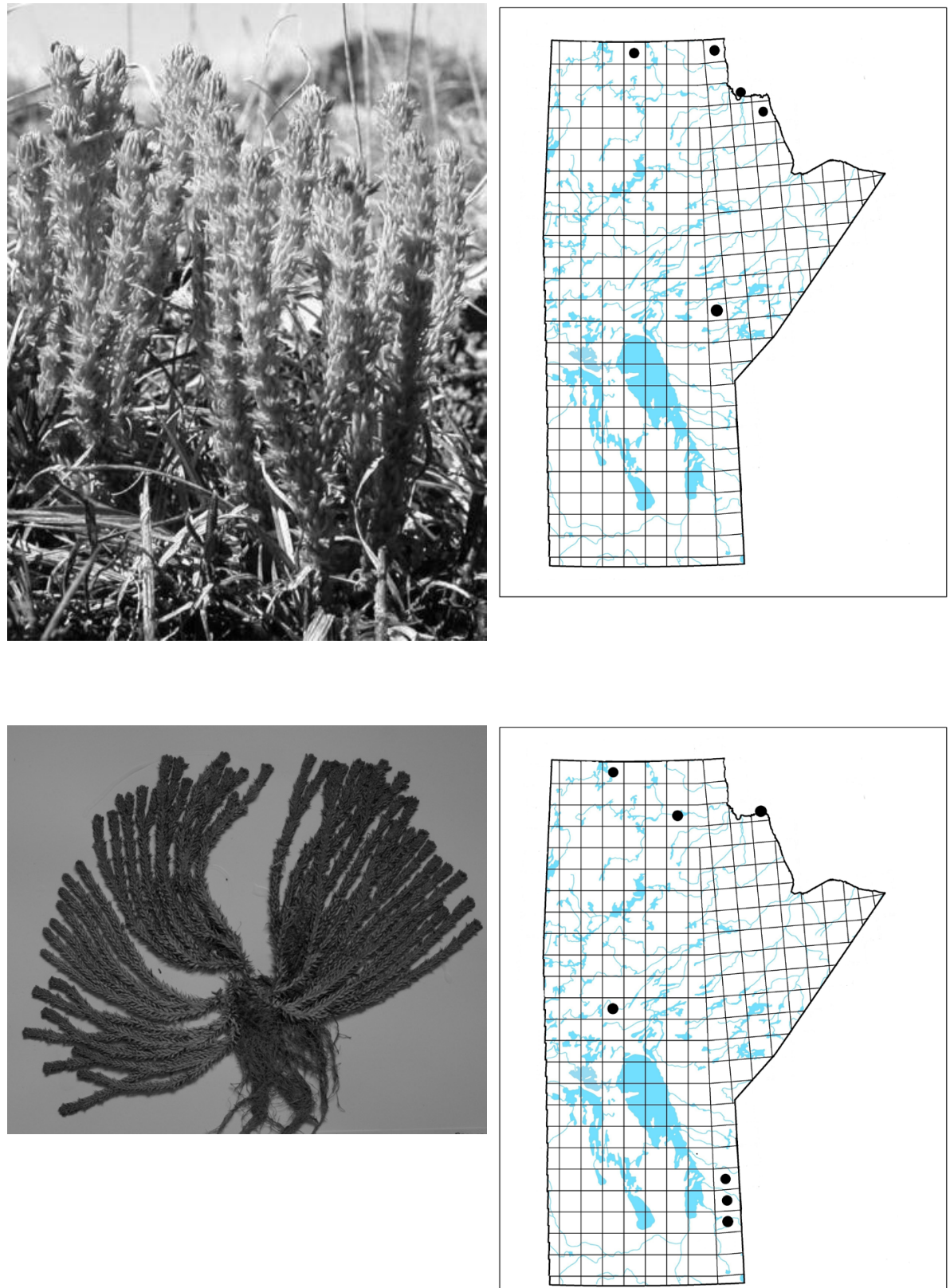

Figure 8. Upper photograph and map: Mountain firmoss, Huperzia appressa. Lower photograph and map: Northern firmoss, Huperzia selago. 

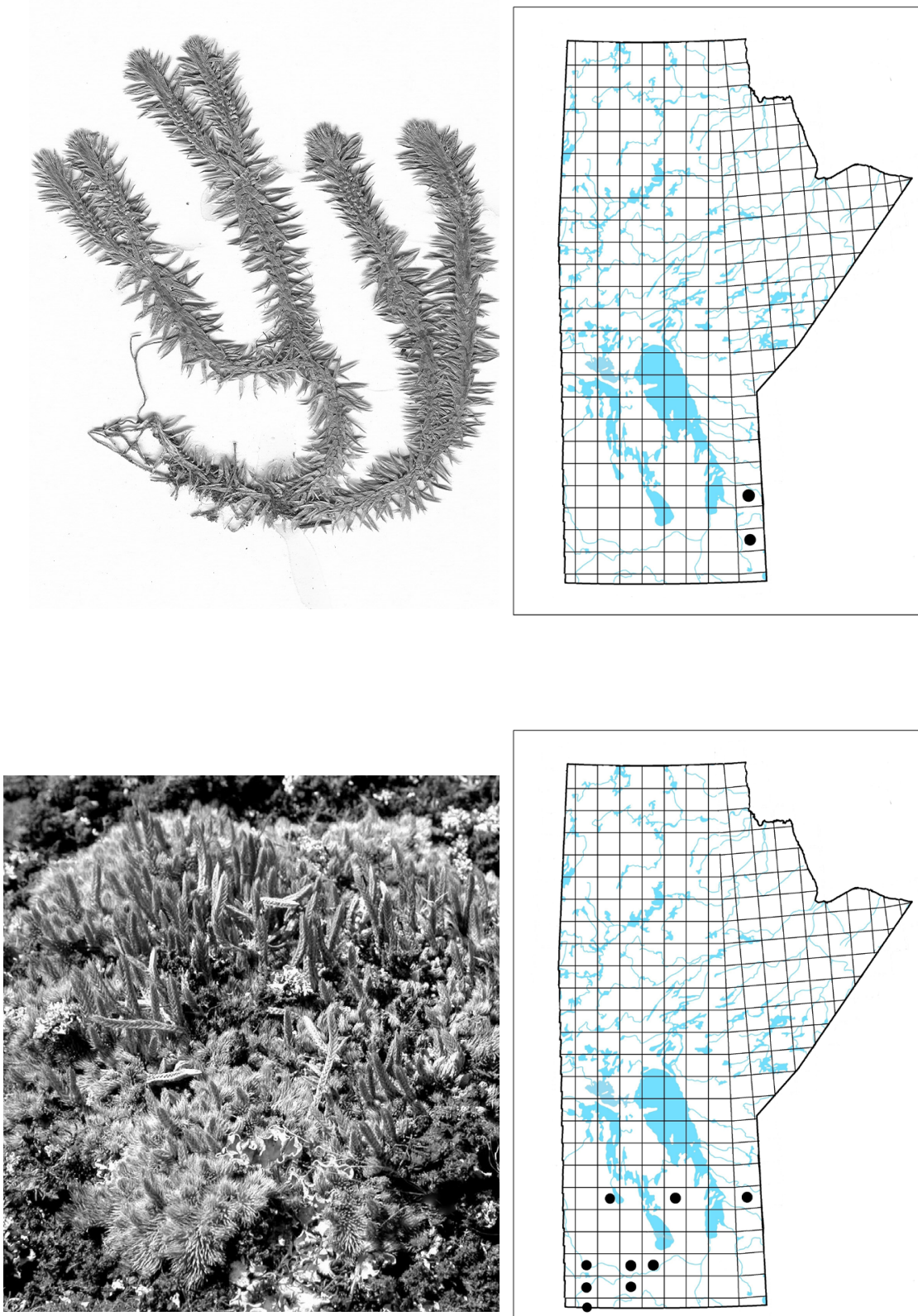

Figure 9. Upper photograph and map: Butters' firmoss, Huperzia x buttersii. Lower photograph and map: Prairie spikemoss, Selaginella densa. 

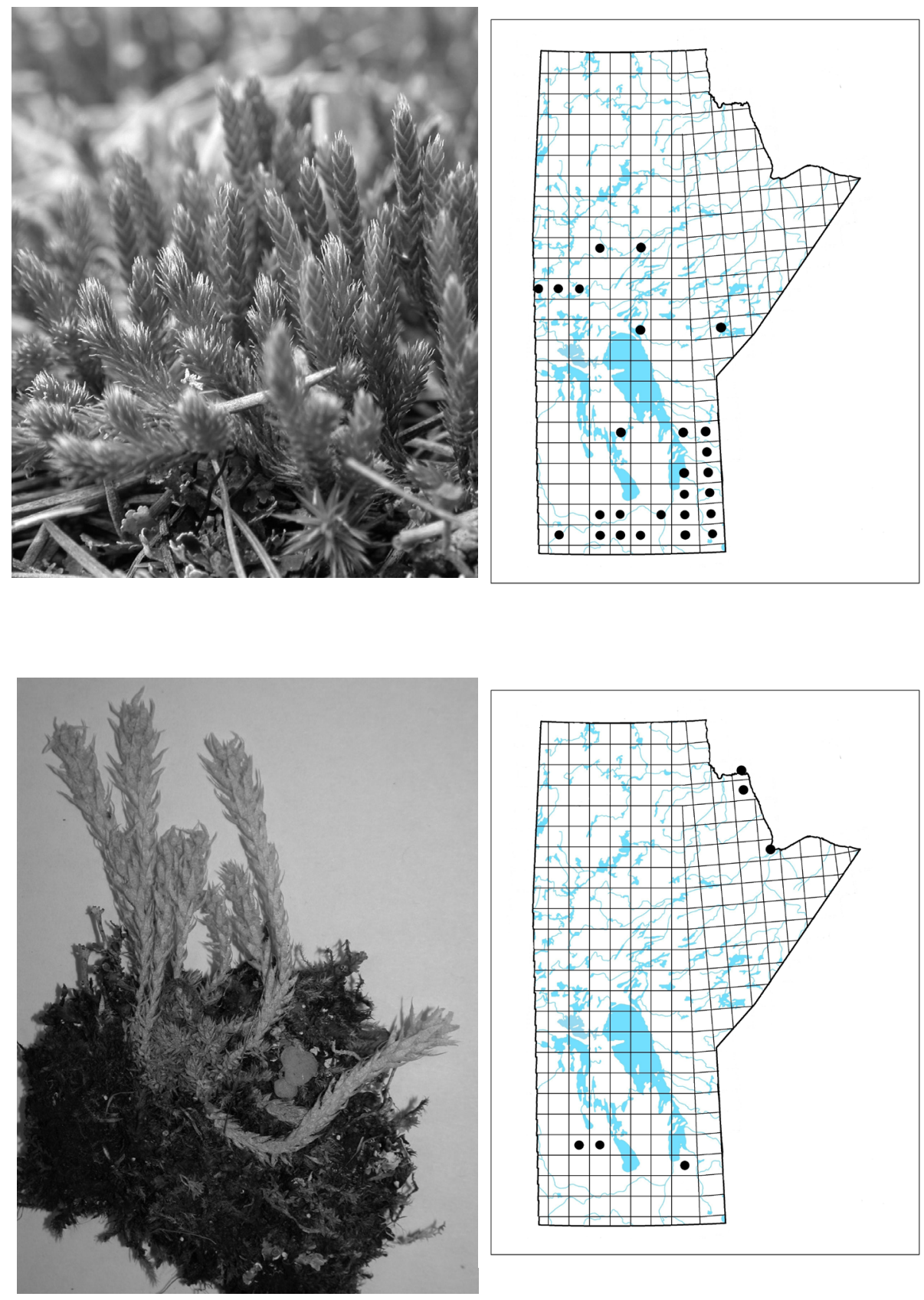

Figure 10. Upper photograph and map: Rock spikemoss, Selaginella rupestris. Lower photograph and map, Northern spikemoss, Selaginella selaginoides. 

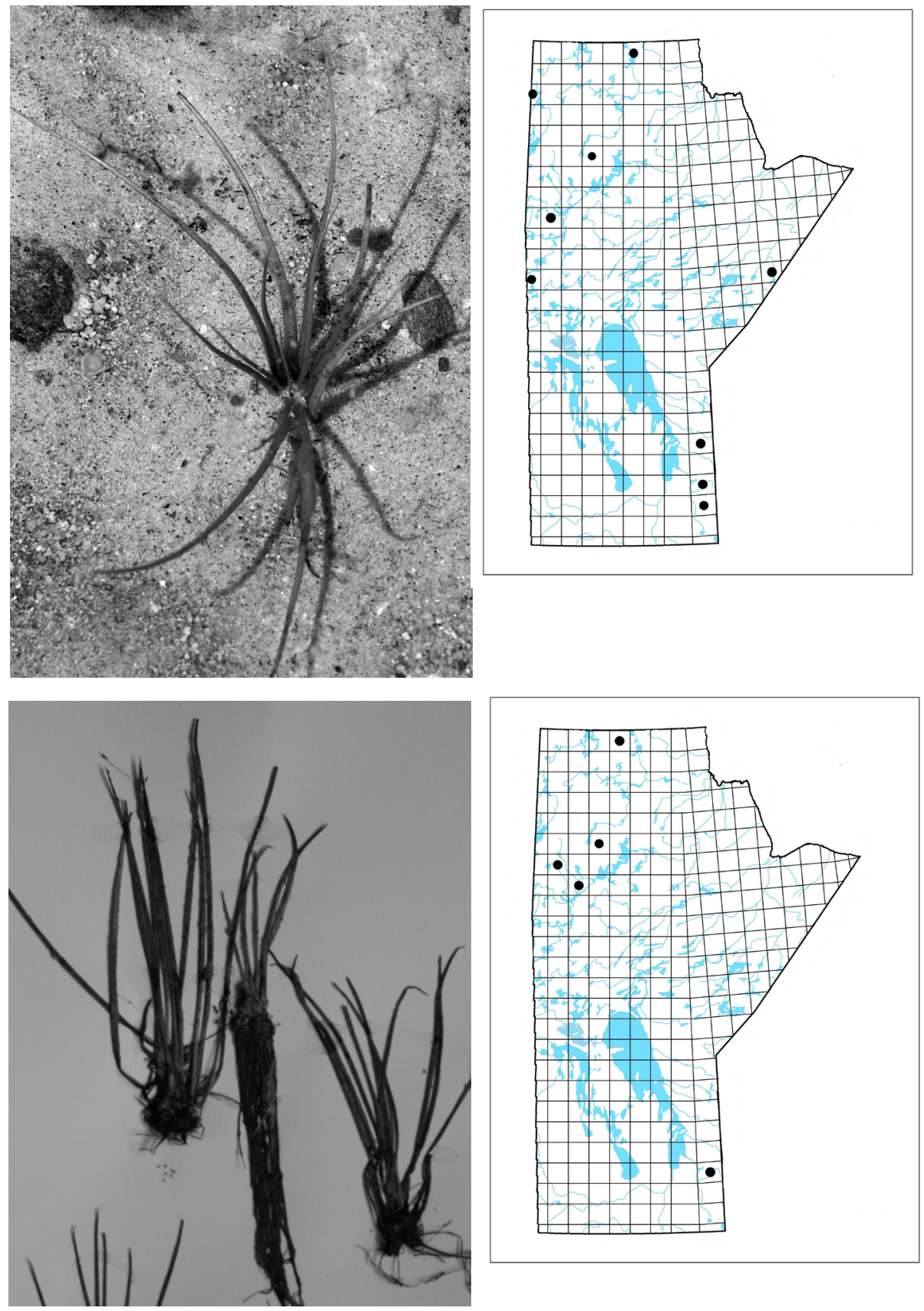

Figure 11. Upper photograph and map: Spiny-spored quillwort, Isoëtes echinospora. Lower photograph and map: Lake quillwort, Isoëtes lacustris. 


\section{Acknowledgements}

I am grateful to Diana Bizecki Robson and Janis Klapecki, Bruce Ford and Elizabeth Punter and German Avila-Sakar for their encouragement and access to the plant collections at The Manitoba Museum, The University of Manitoba and University of Winnipeg, respectively. Special thanks go to Colin Murray for his patience and expertise in drafting the original distribution maps. Chris Friesen and staff at the Manitoba Conservation Data Centre helped locate specimens that I was unable to find and gave advice with Conservation Status Ranks. Finally, thanks go to Jessica Elliott of Parks Branch, Manitoba Conservation for facilitating collection permits for Provincial Parks.

1. Judd WS, Campbell CS, Kellogg EA, Stevens PF, Donaghue MJ (2002) Plant systematics. A phylogenetic approach. $2^{\text {nd }}$ edn. Sinauer Associates, Inc. Sunderland, MA.

2. Moran RC (2004) A natural history of ferns. Timber Press, Inc. Portland, OR. 3. Cody WJ, Britton DM (1989) Ferns and fern allies of Canada. Publication 1829/E. Research Branch, Agriculture Canada, Ottawa, ON.

4. Harms VL and Leighton AL (2011) Ferns and fern allies of Saskatchewan. Flora of Saskatchewan Fascicle 1. Nature Saskatchewan Special Publication \#30. Publ. by Flora of Saskatchewan Association and Nature Saskatchewan. Regina. SK.

5. Staniforth RJ (2011) Ophioglossid ferns in Manitoba: moonworts, grapeferns and northern adder's-tongue. Blue Jay 69(2) 75-87.

6. Haines A (2003) The families Huperziaceae and Lycopodiaceae of New England: A taxonomic and ecological reference. VF Thomas Company, Bowdoin, ME.

7. The Flora of North America Association (1993) Flora of North America, Vol 2: Pteridophytes and Gymnosperms. Oxford University Press, Inc. New York, NY.

8. Online atlas of the British and Irish flora. (2012) Available at: http://www.brc. ac.uk/plantatlas/

9. NatureServe (2010) NatureServe Explorer: an online encyclopedia of life [web application]. Version 6.0. NatureServe, Arlington, VA. Available at http://ww.natureserve.org/explorer

10. Punter E (1995) Manitoba's vascular plants. Manitoba Conservation Data Centre, Winnipeg, MB.

11. Scoggan HJ (1957) Flora of Manitoba. National Museum of Canada. Bulletin No. 140. Biological series No. 47. Department of Northern Affairs and National Resurces, Ottawa, ON.

12. Scoggan HJ (1977) The flora of Canada. Part 2 Pteridophyta, Gymnospermae, Monocotyledoneae. National Museum of Natural Sciences. Publications in botany, No. 7(2). National Museums of Canada, Ottawa, ON.

13. Holland G, Ottenbreit K, Punter D, Punter E, Shanks A, Staniforth R (1996) Wild plants of Birds Hill Provincial Park, Manitoba, Canada. Manitoba Naturalists Society, Eco Series 4. Winnipeg, MB.

14. Cobb B, Farnsworth E, Lowe C (2005) A field guide to the ferns and their related families. Northeastern and Central United States. $2^{\text {nd }}$ edn. The New England Wildflower Society. The Peterson Field Guide Series. Houghton Mifflin Company, New York, NY. 
15. Hickey RJ (1977) The Lycopodium obscurum complex in North America. American Fern Journal 67:45-48.

16. Holub, J (1975) Diphasiastrum, a new genus in Lycopodiaceae. Preslia 14: $97-100$.

17. Harms VL (2003) Checklist of the vascular plants of Saskatchewan and the provincially and nationally rare native plants in Saskatchewan, including important synonyms, authorities, common names and various status indicators. University Extension Press, Saskatoon, SK
18. Cody WJ (1988) Plants of Riding Mountain National Park, Manitoba. Research Branch, Agriculture Canada, Publication 1818/E, Supply and services Canada, Ottawa, ON.

19. Tryon RM Jr (1954) The ferns and fern allies of Minnesota. University of Minnesota Press, Minneapolis, MN.

\section{ECOSYSTEMS}

\section{THE UKRAINIAN STEPPE: STATUS, THREATS AND PROMISES OF SUSTAINABILITY}

VLADIMIR V. KRICSFALUSY School of Environment and Sustainability, University of Saskatchewan, 330 Kirk Hall, 117 Science Place, Saskatoon SK S7N5C8, Canada vladimir.k@usask.ca

\section{INTRODUCTION}

Grasslands and savannas are found in most terrestrial ecoregions of the world and they cover over $40 \%$ of the land surface. ${ }^{1}$ Following the Pleistocene ice ages, grasslands expanded in range in the hotter and drier climates. Eventually, they became the dominant land feature worldwide. Nowadays, grasslands occupy more of the earth's surface than the other major cover types, i.e. forests or agricultural lands. Along with this huge sweep of area, grasslands are an immensely important environment for humans, plants and animals.
Grassland communities are characterized by rich biodiversity. The vegetation is dominated by grasses and other graminoids such as sedges. Grasses and many sedges are particularly suited for the specific ecological conditions because they have intercalary meristems that allow for continued growth under a grazing regime and help ensure survival in dry summers and cold continental winters. Most grassland plants also have a welldeveloped fibrous root system with a large surface area, a characteristic which is important under the condition of low soil moisture. 